\title{
G20 Governance for an Inclusive Liberal Order*
}

\author{
John Kirton \\ G20 Research Group, Trinity College \\ University of Toronto \\ Toronto, ON, Canada M5S $1 \mathrm{H} 8$ \\ john.kirton@utoronto.ca
}

Published 6 December 2018

\begin{abstract}
The Group of Twenty (G20) was created first at the ministerial level and later upgraded to the summit level as a response to the global financial crises that first erupted from Asia in 1997, and then from the US in 2008 and Europe in 2010. These crises called into question the core principles and practices of the liberal order based on the economic, social and political openness that had been progressively internationally institutionalized since 1944. The G20 was designed with a dual distinctive foundational mission to promote financial stability and to make globalization work for all. It combined all established and emerging economies with high capability and connectivity, to operate as equals, to protect all within their borders and those beyond. It increasingly did so since its first summit in 2008. Its performance spiked at the summit in Hangzhou, China, on 3-4 September, 2016, and again at Hamburg, Germany, on 7-8 July, 2017. The latter coped with the new populist, protectionist US president and UK prime minister, whose countries had hosted the first three summits. G20-supported initiatives and agreements for full free trade have advanced since the first summit in 2008. No other center of global summit governance has emerged to guide an increasingly globalized world. The G20 has also steadily become an effective governor of global security. As the forces that propelled this rise will intensify, the Argentinian-hosted G20 summit on 30 November-1 December, 2018, promises to proceed along this path. It is
\end{abstract}

\footnotetext{
*This article is based in part on a paper first prepared for presentation at a "G20 Experts' Seminar", sponsored by the Ministry of Foreign Affairs, Seoul, Korea, on 5 December, 2017. This is an Open Access article, copyright owned by World Scientific Publishing Company (WSPC) and School of International Relations and Public Affairs of Shanghai International Studies University (SIRPA of SISU). The article is distributed under the Creative Commons Attribution 4.0 (CC BY-NC) Licence. Further distribution of this work is permitted, provided the original work is properly cited and for non-commercial purposes.
} 
guided by a country again afflicted by a financial crisis but now dedicated to following the core liberal order and making it work better for all. The real test will arrive in 2019, when Japan as host must co-operate with Korea and China, its neighbouring Asian powers and previous G20 hosts, to provide a new center of inclusive, progressive, liberal global governance that the world badly needs.

\section{Keywords}

G20; governance; international organizations; globalization; compliance.

\section{Introduction}

In late September 2018, US President Donald Trump addressed the United Nations General Assembly in New York and chaired a session of the United Nations Security Council (UNSC) there. He outlined his vision of a new world order which rejected "globalism" and put "patriotism" in its place. In sharp contrast, China's foreign minister, echoing President Xi Jinping's earlier speech at the World Economic Forum in Davos, affirmed the core principles of the established liberal economic order that the largely Western powers led by the US had put in place after their victory in the Second World War (Ikenberry, 2001).

A similar contrast is likely to arise when Presidents Trump and $\mathrm{Xi}$ Jinping meet at the Group of Twenty (G20) summits in Argentina in November 2018 and Japan in June 2019. There they and their G20 colleagues will confront many challenges to establish the economic order bred by emerging financial crises from Argentina, Turkey and elsewhere, the UK leaving the European Union (EU), growing inequality, populism and protectionism across a retreating Atlantic world, rising Asian rivals, and the existential threats of nuclear proliferation from North Korea, and above all climate change. Few expect a G20 summit so divided between the visions of its two most powerful leaders to provide a unified response, let alone one that reinforces the established liberal order and reforms it in ways that meet these current needs.

Their doubts are based on the dominant view of how G20 summits have performed to date. Here, there has been a great debate among the many who see the G20 summit destined to decline or disappear following the great global financial crisis of 2008 that catalyzed its birth and the few who expect it to rise and expand (Kirton, 2013). This debate has recently intensified on the specific question of whether G20 has reinforced or 
reformed the established liberal order and the oligarchy of largely Western powers at its core. The first school of reinforcers sees G20 largely sustaining the old oligarchy and the traditional liberal values they prefer, while failing to protect the workers and thus eroding the compromise of embedded liberalism at its core (Cooper and Pouliot, 2015; Naylor, 2018; Polaski, 2018; Ruggie, 1993). The second school of de-liberalizing reformers sees G20 and BRICS challenging "the EU's approach to the global order, rooted in effective multilateralism... with respect for European core values, including issues such as the rule of law and human rights" (Wouters and Van Kerckhoven, 2018, p. 70). The third school of progressive reformers sees G20 effectively sustaining an open liberal order while strengthening its inclusiveness and equality, in both the traditional field of macroeconomic policy and the emerging area of digitalization (Prilepskiy, 2018; Kirton and Warren, 2018).

This study largely supports the latter case, showing a G20 increasingly, if incompletely, providing effective global governance to build a more inclusive, liberal world order that shapes globalization for the benefit of all (Kirton, 2014, 2015, 2017b). Since its start at the ministerial level in 1999, the G20 has conquered past physical crises, notably in 1997-1999 and 20082009, and the political crises of confidence in the liberal order that came with them. It has done so by faithfully following its distinctive foundational mission, to make globalization work for all, as a well-designed body with a membership of established and emerging, intensely interconnected and equally vulnerable countries, any of which can suddenly need help from all.

G20 summit performance rose from its 2008 start and surged at Hangzhou in September 2016 (Kirton 2016a, 2016b). It then soared at Hamburg in July 2017, where it largely survived the stress test imposed by the arrival of US President Donald Trump. During this time the G20 fostered new free trade agreements and became an effective global security governor. No serious rivals appeared to challenge its leaders' 2009 decision to choose G20 as the primary permanent forum for their international economic co-operation. The forces that propelled this growing inclusive, liberal G20 governance will strengthen in the coming years. Thus, Argentina's Buenos Aires Summit in 2018 and Japan's Asian Summit in Osaka in 2019 promise to overcome the present populist, protectionist, parochial threats and strengthen this inclusive liberal order in the years ahead. 


\section{Controlling Globalized Crises Since 1971}

Global financial and other crises have proliferated since 15 August, 1971, when a once hegemonic US, soon to be militarily vanquished in Vietnam, unilaterally assaulted the liberal, open, rules-based, multilateral monetary and trade order it had pioneered since 1944. The so-called "Nixon shock" and the subsequent bankruptcy of New York City catalyzed the creation of the Group of Seven (G7) summit of major democratic powers in 1975. The new, non-state-created, non-targeted, genuinely global financial crisis arising from Asia in 1997 spurred the finance ministers of Canada and the US, both of which were still haunted by the vivid memories of the Mexican peso crisis in December 1994, to establish in 1999 the G20 for the finance ministers and central bank governors of a new class of systemically significant states. Soon after, the deadly terrorist attacks on the US on 11 September, 2001, made G20 an effective security governor for the compelling issue of combatting terrorist finance, including in the Al-Qaeda homeland of Afghanistan. It bonded the new Bush administration to the group. President George W. Bush later elevated G20 to a summit to address the much larger American-turned global financial crisis that erupted in New York City on 15 September, 2008. The G20's move from crisis response to a crisis prevention body arose at the G20's Canadian- and Korean-hosted summits in 2010, the French-hosted summit in 2011 and the Mexicanhosted summit in 2012, which stopped the new European crisis from going global. This G20 summit success has endured to this day, despite the emergence in 2018 of country-contained financial crises in Argentina and Turkey.

\section{Conquering Crises of Confidence in the Liberal Order Since 1971}

These physical crises each brought a psychological and political crisis of confidence in the 1944 liberal multilateral order based on open economies, societies and polities, backed by the principles of democracy, human rights and an "embedded liberalism" that nationally protected citizens within still largely closed sovereign states at the core (Ruggie, 1993). After each crisis made such states and their citizens more internationally exposed, the G7, and its G20 successor, responded just enough and just in time to enable this 
evolving liberal order to survive and thrive, especially as the democratic revolution went global after 1989 .

These crises of confidence first arose amidst the stagflation of the 1970s and the deep global recession of 1980-1985, with which an often divided democratic world had to cope. The rising, if never dominant, free market fundamentalism of the so-called Washington Consensus was challenged, along with its International Monetary Fund (IMF) adherents, when the 1997 financial crises devastated the emerging Asian economies of Thailand, Indonesia and Korea, followed by Russia, Brazil and for a moment threatened the US itself in the autumn of 1998. In 1999 the Group of Eight (G8) summit, now with Russia added to G7, responded with the "Cologne Consensus" on socially sustainable globalization. Its key principles became the two distinctive core missions of the "finance G20" created that year. The much bigger 2008 crisis bred calls for a "new Bretton Woods", but in practice brought a focus on restoring financial stability through a new macro-prudential approach and macroeconomic growth through orthodox Keynesian tools (Drezner, 2015; Luckhurst, 2016).

\section{Designing a Distinctive Mission, Membership and Reversing Roles}

Once the G20 had achieved its first foundational mission of promoting global financial stability, it turned to focus on its second of making globalization work for the benefit of all. Both united the G20's established and emerging economies, each made systemically significant by their combined capability and connectivity and, thus, vulnerability. The crises from the US in 2008 and Europe in 2010 brought a great role reversal, when the major providers of financial security in 1994 and 1997 became the leading consumers of financial security, needing a bailout from those that had been on the other side of the crises before. Among G20 members, China, Japan, India, Canada, Australia, Saudi Arabia and South Africa had no homegrown financial crisis in either phase, but still suffered from the contagion caught from others. Some of these latter countries could catalyze the contagious crises that could arise in the months or years ahead. ${ }^{1}$

\footnotetext{
${ }^{1}$ Canada, seen as a bastion of financial stability in 2008, currently leads the world in the level of consumer debt per capita, with inflated asset prices in real estate reminiscent of the US housing bubble in 2008 .
} 


\section{Rising Performance through to Hamburg's Surge, 2008-2017}

After this great role reversal, G20 summit performance steadily rose, across all key dimensions of governance that international institutions have (see Appendix A). On the first dimension, domestic political management, the leaders' attendance did decline from $100 \%$ at the first three summits to $90 \%$, whereas it stabilized for the next seven, and then rose to 95\% at Hangzhou in 2016 and Hamburg in 2017. In its public deliberation, the G20's communiqués steadily expanded from 3,567 words in 2008 to 28,766 in 2013, then plunged to 5,983 in 2015 , but soared to a new high of 34,746 at Hamburg in 2017. In its principled and normative direction setting, the number of G20 affirmations of financial stability was surpassed by those of inclusive globalization for all since 2013, while those of the politically liberal principles of democracy were strong and those of individual liberty and human rights rose in 2016 and 2017 (see Appendices B.1 and B.2).

In its decision-making, the G20's public, collective, precise, future-oriented, politically-binding commitments expanded rather steadily, from 95 in 2008 at Washington to 213 in 2016 at Hangzhou and then surged to 529 in 2017 at Hamburg. In the delivery of these decisions, through members' compliance with their priority commitments from the summit where until the subsequent one, average compliance was always positive, if only $57 \%$ with London in 2009 and at least $67 \%$ in all other years. It reached a new high of $85 \%$ at the interim, eight-month mark with the priority commitments made at Hamburg in 2017.

In the institutionalized development of global governance inside G20, the number of its ministerial forms expanded since 2010. From only finance ministers and central bank governors at its start in 2008, it reached a total of six by 2017. It did so by adding labor, agriculture, foreign affairs and, for the first time, digitalization and health, with ministerial meetings for tourism, development, trade and energy taking place in previous years (see Appendix C.1). In official-level working or study groups, the four created in 2008 expanded to 13 in 2018, with new ones for infrastructure, education and women business leaders (see Appendix C.2). Civil society engagement groups arose formally in 2010 and expanded to seven by 2017, with informal ones also emerging along the way (see Appendix C.3).

The 2017 Hamburg Summit hit new highs in performance, despite the presence for the first time of a populist, protectionist Donald Trump, who had just announced US withdrawal from the Paris Agreement on climate 
change (Kirton, 2017c). G20 leaders, led by the host German Chancellor Angela Merkel, found a way to work with Trump to advance co-operation on the key issues of terrorism, North Korea, women's economic empowerment, the marine environment and much else. They also found a way for the 19 of them to collectively act to control climate change, until the executive branch of the US Government would rejoin the campaign. The Hamburg Summit's overall, highly inclusive liberal message, declared even more strongly than the 1940's compromise of embedded liberalism, was that the economy should serve society, not the other way around (Snower, 2017; Ruggie, 1993).

\section{Fostering New Free Trade Agreements}

With the support of G20, trade liberalization is surviving Trump's severe stress test. Indeed, it is expanding and flourishing despite the strengthening headwinds from him and a "Brexiting" Britain. The EU has entered the North American market with its now ratified Canada-European Union Comprehensive Economic and Trade Agreement (CETA). It is also concluding a stronger one with Mexico, Canada's partner in the North American Free Trade Agreement (NAFTA). Canada completed a free trade deal with Ukraine and is exploring or negotiating others with India, Japan, the Association of South East Asian Nations (ASEAN) Mercosur and the Pacific Alliance, among others. China is building the Regional Comprehensive Economic Partnership. The Trans-Pacific Partnership (TPP) was successfully completed as TPP-11, after Trump pulled the US out, with Canada making it a more socially embedded liberal "comprehensive, progressive" TPP in November 2017. Trump has succeeded in stopping trade liberalization only for his own US and the firms that stay there. Although he prefers bilateral to multilateral deals, he has found no one willing to deal with him, although at the end of September 2018, Japanese Prime Minister Shinzo Abe told Trump he would initiate such talks. The G20 had managed US and others' concerns about the steel trade, until Trump imposed steel and aluminum tariffs on a wide array of G20 partners in 2018. Yet, US threats to end its Korean free trade agreement ended when the two agreed to a modestly revised deal. The US also did so with Mexico in September 2018 and is continuing talks to do so with its other NAFTA partner, Canada, as well. The US Transatlantic Trade and Investment 
Partnership had largely escaped Trump's complaints and in 2018 the US and the EU agreed to a protectionist halt.

There are thus good grounds to expect G20 to become a stronger center of global trade liberalization governance, in a way that the World Trade Organization (WTO) cannot without G20's help. This was seen in the critical, catalytic role played by the G20's Brisbane Summit in 2014 in concluding the trade facilitation agreement. It is seen more broadly in the G20 summit's trade governance since its very start. The G20 summits from 2008 to 2017 made 164 trade commitments, starting with five at Washington in 2008 and soaring to new highs of 24 at Hangzhou in 2016 and 29 at Hamburg in 2017 with Donald Trump there. Compliance by G20 with the priority commitments was a positive $62 \%$. Compliance with the assessed 2015 commitments from Antalya soared to 80\% and those from 2016 at Hangzhou to $83 \%$.

Compliance was higher with those commitments that did not refer to the WTO and in years where more G20 trade commitments were made. Compliance with the leaders' trade commitments was also higher in years where G20 meetings of trade ministers were held. These only started in Mexico in 2012, and after an absence in 2013, continued in 2014, 2015 and 2016, but not 2017. G20 trade governance is thus effective, especially when it is directed at liberalization beyond the rigid confines of the WTO.

\section{Strengthening Global Security Governance}

Although trade was a key part of the G20 summit agenda at its 2008 start, security was not, especially in the specialized form of terrorist finance that the finance G20 had pioneered in 2001. Yet, since 2008 the G20 summit has addressed broader security threats (Lee, 2010). It steadily became an effective global security governor over an expanded terrain, from the nonstate threats of terrorist finance, through money laundering, tax evasion, crime, corruption and terrorism as a whole, to the high, hard, state-initiated security threats of the proliferation, and use of weapons of mass destruction in their chemical and nuclear forms (Kirton, 2017a). It delivered a singular success at its 2013 St. Petersburg Summit by helping stop Syrian President Bashar Al-Assad from routinely using chemical weapons, at least until US President Barack Obama was replaced by Donald Trump after the presidential election of November 2016. At the opening, leaders-only 
session at Hamburg in 2017, Trump and his colleagues discussed North Korea's nuclear weapons proliferation and appeared to come to a consensus that led to a UNSC resolution to sanction North Korea, with UNSC Permanent Five members China and Russia in support.

More broadly, meetings on the margins of G20 summits have had useful security effects. These ranged from the message on Iran's nuclear program from Pittsburgh in 2009 to the discussions about and with Russian President Vladimir Putin over his aggression in Ukraine in the preparations for and at Brisbane in 2014. Moreover, the G20 foreign ministers' meeting expanded in several ways, from its fragile beginning in Los Cabos, Mexico, in 2012, to its long-planned gathering on the road to Hamburg in 2017.

Terrorism, as the G20's first security subject, will not go away nor will it be stopped by Trump's unilateral, border-closing approach in the US, as the deadly attacks in New York City showed in November and December 2017. The terrorist threat is well known to future G20 hosts, as it has already touched Argentina, Japan in the 1995 sarin gas attacks and, above all, Saudi Arabia, which will host the G20 in 2020. Nuclear proliferation from North Korea and Iran will also preoccupy the latter two hosts.

\section{Missing Global Governance Rivals}

The strengthening success of the G20 summit is further shown by the fact that after almost a decade, no other global summit has arisen to rival or replace it, even after it shrunk after 2010 from holding two to only one summit a year. The BRICS summit of Brazil, Russia, India, China and (later) South Africa, beginning in 2009, has largely worked in supportive partnership with the G20 one, especially by holding the BRICS second summit each year at the same time and place as the G20 one. It has not expanded its small membership, beyond adding South Africa in 2010. The older G7 also worked together with G20 in a synergistic partnership, including at the Canadian-hosted twin G8 and G20 summits in Muskoka and nearby Toronto on the same weekend in June 2010 (Kirton, 2017b). The Asia-Pacific Economic Co-operation summit, the ASEAN Summit and the East Asia Summit continue at a steady pace. Chinese-pioneered Silk Road Summitry has just started and remains a very specialized infrastructure-oriented event. Recently created specialized multilateral development banks such as the BRICS New Development Bank and the Chinese-led Asian Infrastructure 
Investment Bank follow the path forged earlier by bodies such as the European Bank for Reconstruction and Development and Islamic Development Bank. To be sure, UN Summitry has intensified. Yet it remains a subjectspecific, siloed ad hoc addition, even with the more comprehensive Sustainable Development Goals arriving in 2015.

\section{Proliferating Propellers of Performance}

The forces that propelled this G20's rising performance will grow in the coming years. The shocks that activate the shared vulnerability of all G20 members and others will intensify to approach critical thresholds, led by the globally existential threats of the proliferation of weapons of mass destruction and climate change, followed by terrorism, territorial disputes, energy, ecology, health, migration and financial threats.

The continuing failure of the core multilateral organizations from the 1940s confirms that there is no place to go other than the G20, if only because those hard law organizations seldom reliably meet at the leaders' level to address all key challenges comprehensively and coherently in an intensely interconnected world. Trump's withdrawal of the US from the Paris Agreement on climate change, the UN Educational, Scientific and Cultural Organization and the Global Compact on Migration compounds the failure. ${ }^{2}$ In trade, the WTO has not completed a multilateral trade negotiation round in over two decades and its appellate body will soon be made moribund by a US president who rejects multilateral trade liberalization and refuses to appoint US judges to it. The IMF, with its unique US veto, does better, but is unlikely to undertake the promised next round of voice and vote reform to give rising emerging powers their promised, proportionally enhanced place. The World Bank Group, its co-located and US-headed twin, is more vulnerable to US financial cutbacks for development, but did make an important step forward in spring $2018 .^{3}$

\footnotetext{
${ }^{2}$ In contrast, the US continues to invest in plurilateral arrangements, even in the environmental field, as in the November 2017 agreement among 10 countries including China and Japan to prevent fishing beneath the warming, opening Arctic ice, before the scientific sustainability of such an agreement can be assessed.

${ }^{3}$ These are particular challenges for Korea and France, as co-chairs of the G20's International Financial Assistance Working Group, which must address the 15th Quota Review, and replenishment of the International Development Association.
} 
G20 members will continue to possess a strong predominance of collective global capability. ${ }^{4}$ Members' internal equality will strengthen, as reviving growth in G7 members is outstripped by the levels of a slightly slowing China and India, with a currently beleaguered Brazil, Russia, South Africa, Argentina, Turkey and others likely to revive in the medium term.

Convergence on the common liberal principles of open economies, societies and polities provides a serious constraint in the political realm, with the current closure in Russia, Turkey and elsewhere. Yet there is offsetting openness, backed by action against corruption, in Argentina, Brazil and elsewhere. Political cohesion is problematic in the G7 powers of the US, UK, Italy and even Germany. Yet it should remain strong in Japan, France, Canada, China, India, Argentina and Russia. The experience from Seoul in 2010, through St. Petersburg in 2013, to Hamburg in 2017 suggests that G20 will continue to slowly become a cherished interpersonal club at the hub of a growing network of global summit governance with new spokes such as the Silk Road Summit added all the time (see Appendix D). ${ }^{5}$

\section{Promising Planning for Argentina's Summit, 2018}

The prospect of an increasingly effective G20 expanding the liberal order is enhanced by the promising plans of Argentina to host a 2018 summit centered on producing liberal prosperity for all. In publicly introducing his approach to the summit, Argentina's President Mauricio Macri called the G20 "the world's preeminent forum for ... political co-operation" and stated that his goal is to have it "commit to fair and sustainable economic development that generates opportunities for everyone" (Argentina's G20 Presidency, 2017). His Foreign Minister, Jorge Faurie, added: “Argentina's intelligent integration with the international community is based on our nation's key values: democracy, freedom and human rights."

\footnotetext{
${ }^{4}$ The 2018 Argentinian host identified collective global capability on 30 November, 2017, as $85 \%$ of global economic output, $80 \%$ of global investment, $75 \%$ of international trade and $66 \%$ of global population.

${ }^{5}$ One sign is Argentina's decision to invite seven guests to its summit, all democratic countries, with Jamaica representing the 20 all-democratic and small-state members of CARICOM.
} 
Argentina has offered a full-strength agenda rather than one narrowly focused on the alleged fundamentals, as was the case with the poorly performing Brisbane Summit in 2014 (see Appendix E.1). Argentina's nine priority subjects, identified well before its year as host began on 1 December, 2017, were fewer than the 15 Germany had at the launch of its Hamburg year (see Appendix E.2). Yet, these will probably expand as Argentina's year unfolds, with macroeconomics, financial regulation, reform of the international financial institutions (IFIs) and terrorism added to the list. The existing agenda represents a blend of continuity and creativity, with the latter featured as the first priority - the future of work in the digital age.

The presence of trade, energy and climate change on the 2018 agenda shows that Argentina will continue to promote economic openness, undeterred by the protectionist, populist, climate-skeptical Donald Trump. Indeed, as the current NAFTA negotiations among the US, Canada and Mexico show, the digital age demands a new set of rules to reinforce open trade, along with stronger protections for workers, especially women. On climate change, the "19 without one" formula invented at Hamburg provides a precedent for the Buenos Aires Summit to use, even if the deadly hurricane assaults on the US in the months after Hamburg and in September 2018 or the US congressional election results in November 2018 do not induce the US president to change his mind. However, Argentina's decision to separate energy from climate change and to focus the latter on adaptation rather than mitigation or the Paris Agreement enhances the prospect of finding common ground with President Trump.

\section{Prospects and Potential for Asia's Summit, 2019}

The future of G20 and the inclusive progressive liberal order it has pioneered should continue when the summit returns to Asia in 2019. Yet, this depends on how host Japan works with neighboring Korea and China, as experienced summit hosts, to make its year a progressive liberal success. All three countries are committed to trade liberalization, providing a basis for Northeast Asian regional unity. Most like-minded trade-liberalizing G20 members, including Brexiting Britain, can build on this foundation. North Korea's nuclear proliferation and the campaign against corruption provide a further bond. This could make this summit another security success, which a newly vulnerable US could easily support. Moreover, Chinese 
President Xi Jinping needs to extend his liberal approach to the economy more vigorously to China's own financial system and society. Japan shares similar incentives and has an aging population that propels them.

Korea in 2010 hosted a successful summit, highlighted by its agreement on IFI voice and vote reform and above all on the Seoul Development Consensus that addressed inequality, poverty and resulting populist pressure from those in the Global South. China in 2016 continued its increasing G20 leadership, while confirming that it never leads alone or with a fixed set of partners (Kirton, 2016b). This suggests the possibility of co-leadership in 2019 from the Northeast Asian triumvirate, which collectively contains the second-, third- and 12th-ranked powers in the world (IMF, 2017).

The biggest potential constraint on a Northeast Asian-led G20 summit success in 2019 is the continuation or intensification of regional maritime territorial disputes. Yet here, too, there may be grounds for hope. The BRICS Summit in Xiamen in September 2017 brought China and India back from the brink of their escalating territorial dispute. Moreover, the new vulnerability of an accidental, unauthorized or unintentional North Korean nuclear launch could help the clear, current and continuing danger transcend the traditional rivalry based on the relative capability brought by territory descended from the Westphalian world of almost half a millennium ago. Tipping the balance could be a shared interest in securing the blue economy for the benefit of all in Northeast Asia and far beyond, against the compounding threat of climate change. 
Chinese Journal of International Review

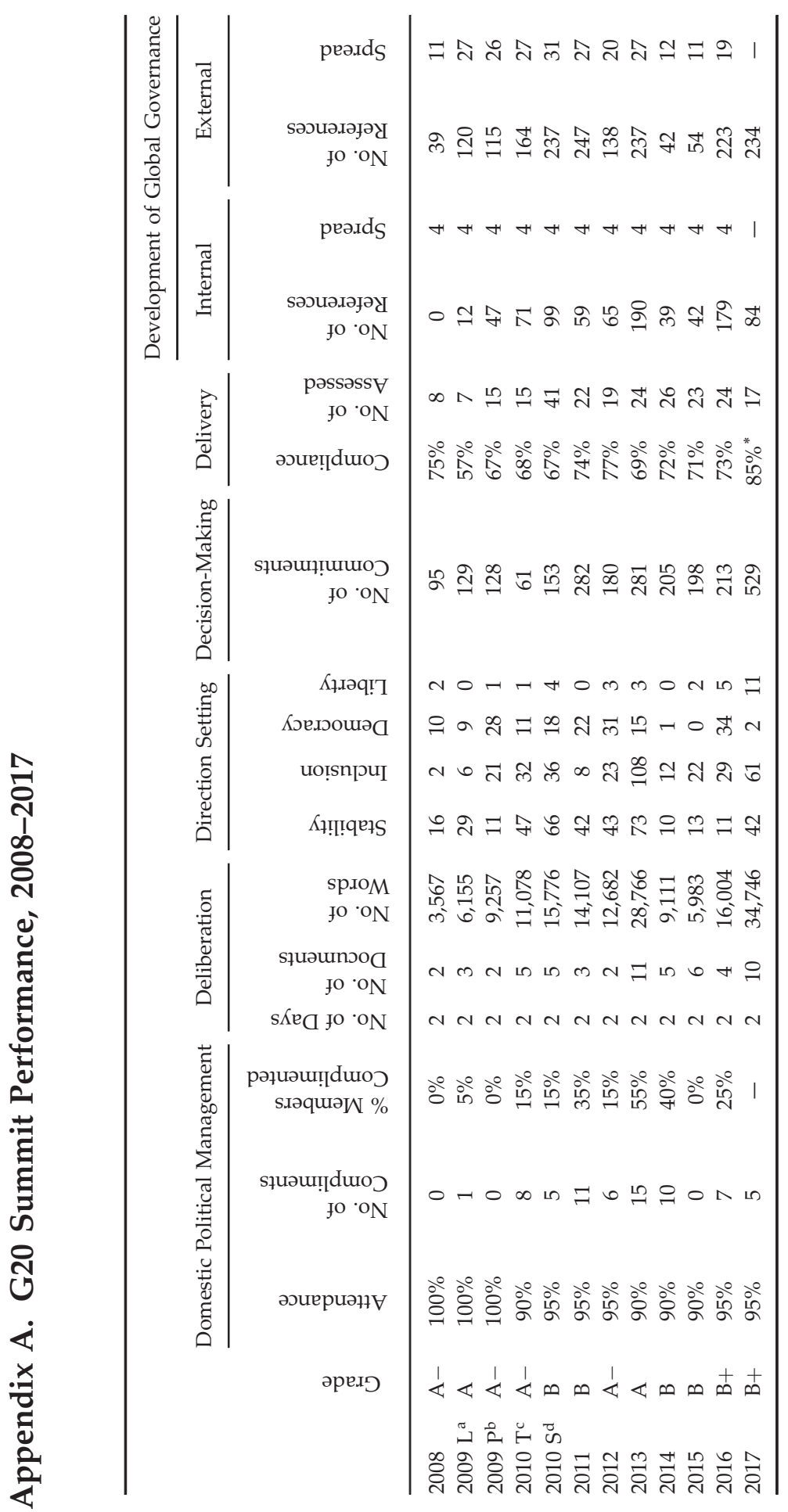




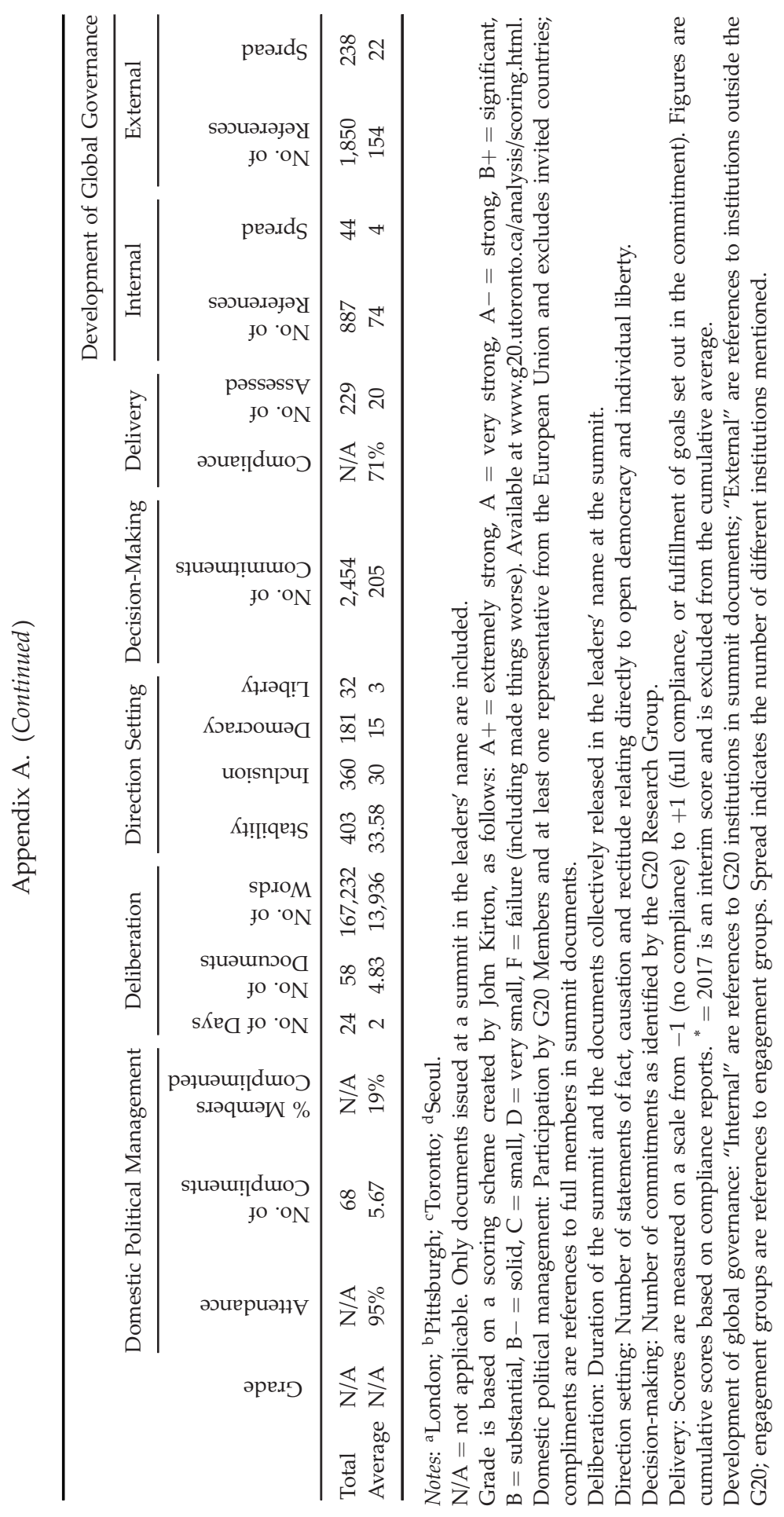




\section{Appendix B.}

\section{B.1. G20 summit direction setting, 2008-2016}

\begin{tabular}{lccr}
\hline Summit & Financial Stability & Globalization for the Benefit of All & Total \\
\hline 2008 Washington & 16 & 2 & 18 \\
2009 London & 29 & 6 & 35 \\
2009 Pittsburgh & 11 & 21 & 32 \\
2010 Toronto & 47 & 32 & 79 \\
2010 Seoul & 66 & 36 & 102 \\
2011 Cannes & 42 & 8 & 50 \\
2012 Los Cabos & 43 & 23 & 66 \\
2013 St. Petersburg & 73 & 108 & 181 \\
2014 Brisbane & 10 & 12 & 22 \\
2015 Antalya & 13 & 22 & 35 \\
2016 Hangzhou & 11 & 29 & 40 \\
2017 Hamburg & 42 & 61 & 103 \\
Total & 403 & 360 & 763 \\
\hline
\end{tabular}

Notes: Coded by Courtney Hallink. The unit of analysis is the sentence.

Inclusions: Financial Stability: Financial Stability Board (FSB), Financial System Stability, Stabilize Impact of Crisis, Prevent Future Crisis, Risk, Resilience; Making Globalization Work for All: Global Partnership for Financial Inclusions (GPFI), Inclusive Growth, Poorest, Poor, Vulnerable, Most Vulnerable Groups, Economic Growth meets Everyone's Needs, Inclusive World Economy, All Parts of the Globe, Gap between Rich and Poor.

\section{B.2. G20 summit principles affirmed}

\begin{tabular}{lccc}
\hline Summit & $\begin{array}{c}\text { Democracy/Individual } \\
\text { Liberty }\end{array}$ & $\begin{array}{c}\text { Financial Stability and } \\
\text { Globalization for the Benefit of All }\end{array}$ & Ratio \\
\hline 2008 Washington & 12 & 18 & $2: 3$ \\
2009 London & 9 & 35 & $9: 35$ \\
2009 Pittsburgh & 29 & 32 & $29: 32$ \\
2010 Toronto & 12 & 79 & $12: 79$ \\
2010 Seoul & 22 & 102 & $11: 51$ \\
2011 Cannes & 22 & 50 & $11: 25$ \\
2012 Los Cabos & 34 & 66 & $17: 33$ \\
2013 St. Petersburg & 18 & 181 & $18: 181$ \\
2014 Brisbane & 1 & 22 & $1: 22$ \\
\hline
\end{tabular}


Appendix B.2. (Continued)

\begin{tabular}{lccc}
\hline Summit & $\begin{array}{c}\text { Democracy/Individual } \\
\text { Liberty }\end{array}$ & $\begin{array}{c}\text { Financial Stability and } \\
\text { Globalization for the Benefit of All }\end{array}$ & Ratio \\
\hline 2015 Antalya & 2 & 35 & $2: 35$ \\
2016 Hangzhou & 39 & 40 & $39: 40$ \\
2017 Hamburg & 13 & 103 & $13: 103$ \\
Overall Total & 213 & 763 & $213: 763$ \\
\hline
\end{tabular}

Note: Coded by Courtney Hallink, 7 January, 2017.

\section{Appendix C.}

\section{C.1. Ministerial meetings}

\begin{tabular}{lcc}
\hline Finance & $1999-2017$ & 2018 \\
Employment and Labor & $2010-2017$ & 2018 (with Education) \\
Tourism & $2010-2013$ & - \\
Agriculture & $2011,2012,2015-2017$ & 2018 \\
Development & 2011 & - \\
Trade & $2012,2014-2016$ & - \\
Foreign Affairs & $2012,2013,2017$ & 2018 \\
Energy & 2015,2016 & 2018 \\
Digitalization & 2017 & 2018 \\
Health & 2017 & 2018 \\
\hline
\end{tabular}

\section{C.2. G20 working and study groups 2018}

\section{- Working Groups/Study Groups}

- Finance track:

- Framework Working Group

- International Financial Working Group

- Africa Advisory Group on Compact with Africa

- Infrastructure Working Group (new)

- Sherpa track:

- Anti-Corruption Working Group

- Climate Change Study Group

- Development Working Group

- Digitalization 
- Education Working Group (new)

- Employment Working Group

- Steel Overcapacity Working Group

- Trade and Investment Working Group

- Women's Business Leaders' Taskforce (new)

\section{C.3. Civil society engagement groups}

\begin{tabular}{lcc}
\hline B20 & Business & 2010, 2011, 2012, 2013, 2014, 2015, 2016, 2017, 2018 \\
L20 & Labor & 2010, 2011, 2012, 2014, 2015, 2016, 2017, 2018 \\
Y20 & Youth & $2013,2014,2015,2016,2017,2018$ \\
C20 & Civil & $2011,2013,2014,2015,2016,2017,2018$ \\
T20 & Think Tanks & $2012,2013,2014,2015,2016,2017,2018$ \\
W20 & Women & $2015,2016,2017,2018$ \\
S20 & Science & 2017,2018 \\
Informal: & & \\
YES & Young Entrepreneurs' Summit & \\
(G)20 & Girls & \\
F20 & Faith & \\
\hline
\end{tabular}

\section{Appendix D. G20 Network through Plurilateral Summit Institutions}

\begin{tabular}{|c|c|c|c|c|c|c|c|c|c|c|c|c|}
\hline & $\begin{array}{l}\infty \\
0 \\
0\end{array}$ & $\sum_{i=1}$ & 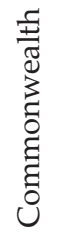 & 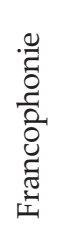 & 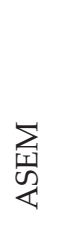 & 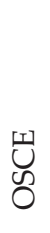 & $\begin{array}{l}\text { U } \\
\text { 焉 }\end{array}$ & 芯 & 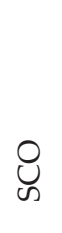 & $\begin{array}{l}0 \\
\text { 宼 } \\
\text { Z }\end{array}$ & $\stackrel{\cup}{0}$ & 퓽 \\
\hline Argentina & & & & & & & & $\times$ & & & & 1 \\
\hline Australia & & $\times$ & $\times$ & & & & $\times$ & & & & & 3 \\
\hline Brazil & $\times$ & $x$ & & & & & & $x$ & & & & 3 \\
\hline Canada & $x$ & $x$ & $\times$ & $\times$ & & $x$ & $\times$ & $\times$ & & $x$ & & 8 \\
\hline China & $\times$ & $\times$ & & & $\times$ & & $x$ & & $\times$ & & & 5 \\
\hline France & $x$ & $\times$ & & $\times$ & $\times$ & $x$ & & & & $\times$ & & 6 \\
\hline Germany & $x$ & $x$ & & & $\times$ & $x$ & & & & $x$ & & 5 \\
\hline India & $x$ & $\times$ & $\times$ & & $\times$ & & & & $x^{b}$ & & & 5 \\
\hline Indonesia & & $\times$ & & & $\times$ & & $x$ & & & & $\times$ & 4 \\
\hline
\end{tabular}


Appendix D. (Continued)

\begin{tabular}{|c|c|c|c|c|c|c|c|c|c|c|c|c|}
\hline & $\begin{array}{l}\text { D } \\
0 \\
0\end{array}$ & $\sum_{\sum=1}$ & 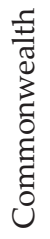 & 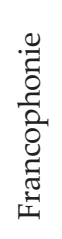 & $\underset{\substack{\text { y } \\
\text { S }}}{\infty}$ & U & $\begin{array}{l}U_{17} \\
\text { 交 }\end{array}$ & ङ & త্ & 怘 & 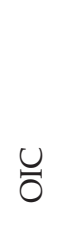 & $\stackrel{\pi}{0}$ \\
\hline Italy & $x$ & $x$ & & & $x$ & $\times$ & & & & $\times$ & & 5 \\
\hline Japan & $x$ & $x$ & & & $x$ & & $\times$ & & & & & 4 \\
\hline Korea & & $x$ & & & $\times$ & & $\times$ & & & & & 3 \\
\hline Mexico & $x$ & $x$ & & & & & $\times$ & $\times$ & & & & 4 \\
\hline The Netherlands & & & & & $x$ & $\times$ & & & & $\times$ & & 3 \\
\hline Russia & $\times$ & $x$ & & & & $\times$ & $\times$ & & $\times$ & & $x^{b}$ & 6 \\
\hline Saudi Arabia & & $x$ & & & & & & & & & & 1 \\
\hline South Africa & $\times$ & $x$ & $\times$ & & & & & & & & & 3 \\
\hline Spain & & & & & $x$ & $\times$ & & & & $\times$ & & 3 \\
\hline Turkey & & & & & & $x$ & & & & $x$ & $\times$ & 3 \\
\hline UK & $\times$ & $x$ & $x$ & & $x$ & $\times$ & & & & $\times$ & & 6 \\
\hline USA & $\times$ & $x$ & & & & $\times$ & $\times$ & $\times$ & & $\times$ & & 6 \\
\hline European Union & $x$ & $x$ & & & $x$ & & & & & & & 3 \\
\hline Total & 14 & 18 & 5 & 2 & 12 & 10 & 9 & 5 & 3 & 9 & 3 & 90 \\
\hline
\end{tabular}

Notes: Includes plurilateral summit institutions of trans-regional reach containing members from the developed and emerging/developing world.

$\mathrm{MEM}=$ Major Economies Meeting; ASEM = Asia-Europe Meeting; OSCE = Organization for Security Co-operation in Europe; APEC = Asia-Pacific Economic Co-operation; $\mathrm{SOA}=$ Summit of the Americas; $\mathrm{NATO}=$ North Atlantic Treaty Organization; $\mathrm{SCO}=$ Shanghai Cooperation Organisation; $\mathrm{OIC}=$ Organisation of Islamic Cooperation.

ancludes Plus Five members.

${ }^{\mathrm{b}}$ India is an observer at the SCO.

\section{Appendix E.}

\section{E.1. G20 Argentina agenda for 2018}

- Future of Work

- Infrastructure

- Trade

- Corruption

- Sustainable Development Goals

- Energy and Climate

- Gender 
- Agriculture

- Health

\section{E.2. G20 Argentina preparatory process for 2018}

- Sherpa track:

- December 14-16: First Sherpa meeting

- Finance track:

- November 30-December 2: Seminar and deputies in Bariloche

- March 19-20: Finance ministers and central bank governors in Buenos Aires

- April 19-20: Finance ministers and central bank governors in Washington, DC (IMF meetings)

- July 21-22: Finance ministers and central bank governors in TBD

- October 11: Finance ministers and central bank governors in Bali (IMF meetings)

- Summit on 30 November-1 December, 2018

\section{References}

Andrew F. Cooper and Vincent Pouliot (2015), "How much is Global Governance Changing? The G20 as International Practice," Cooperation and Conflict, 50(3): 334-350.

Argentina's G20 Presidency (2017), “Republic of Argentina G20 Presidency," Buenos Aires, December 1, http://www.g20.utoronto.ca/2018/2018-Brochure-G20-en.pdf.

Daniel W. Drezner (2015), The System Worked: How the World Stopped Another Great Depression (Oxford: Oxford University Press).

Dennis Snower (2017), "The G20 Summit was More Successful than You Think," G20 Insights, July 11, http://www.g20-insights.org/2017/07/11/g20-summit-successful-think.

Dong-hwi Lee (2010), “The Political-Security Context for the Seoul Summit," in John Kirton and Madeline Koch, eds., G20: The Seoul Summit: Shared Growth Beyond Crisis (London: Newsdesk Media), pp. 166-167. http://www.g20.utoronto.ca/newsdesk/seoul/g20seoul2010. pdf.

Ilya Prilepskiy (2018), “G20 Framework for Strong, Sustainable, Balanced and Inclusive Growth: German Presidency Outcomes and Recommendations for the Argentinian Presidency," International Organizations Research Journal, 13(2): 42-59.

International Monetary Fund (IMF) (2017), “World Economic Outlook Database,” World Economic and Financial Surveys, October 2017 Edition, IMF, Washington, DC, http:// www.imf.org/external/pubs/ft/weo/2017/02/weodata/index.aspx. 
Jan Wouters and Van Kerckhoven (2018), "A European Perspective on the G20 and the BRICS," International Organizations Research Journal, 13(2): 60-75.

John Gerard Ruggie (1993), “Territoriality and Beyond: Problematizing Modernity in International Relations," International Organization, 47(1): 139-174.

John Ikenberry (2001), After Victory (Princeton: Princeton University Press).

John Kirton (2013), G20 Governance for a Globalized World (Farnham: Ashgate).

John Kirton (2014), “The G20 System Still Works: Better Than Ever," Caribbean Journal of International Relations E Diplomacy, 2(3): 43-60. http://www.g20.utoronto.ca/biblio/kirtoncjird.pdf.

John Kirton (2015), "The Future of the Gs: What is in Store?" in Mike Callaghan and Tristram Sainsbury, eds., G20 and the Future of International Economic Governance (Sydney: University of New South Wales Press), pp. 200-214.

John Kirton (2016a), "A Summit of Significant Success: G20 Performance at G20 Hangzhou 2016," G20 Research Group, University of Toronto, September 7, http://www.g20. utoronto.ca/analysis/160907-kirton-performance.html.

John Kirton (2016b), China's G20 Leadership (New York: Routledge).

John Kirton (2017a), “The G20's Growing Security Governance Success," paper prepared for a panel on "Which Global Security Goods can the G20 Provide?" at the "The G20 as a Global Governance Institution" Conference, Federal Academy for Security Policy, Berlin, February 9, http://www.g20.utoronto.ca/biblio/kirton-baks-g20-security.html.

John Kirton (2017b), “Governing Together: The Gx System,” Studia Diplomatica, 68(3): 7-27.

John Kirton (2017c), "A Summit of Significant Success: The G20 at Hamburg," G20 Research Group, July 11, http://www.g20.utoronto.ca/analysis/170711-kirton-performance.html.

John Kirton and Brittaney Warren (2018), “G20 Governance of Digitalization,” International Organizations Research Journal, 13(2): 16-41 (in Russian and English).

Jonathan Luckhurst (2016), G20 Since the Global Crisis (New York: Palgrave Macmillan).

Sandra Polaski (2018), “Expert Opinion: The G20's Promise to Create More and Better Jobs: Missed Opportunities and a Way Forward," International Organizations Research Journal, 13(2): 125-133 (in Russian and English).

Tristen Naylor (2018), Social Closure and International Society: Status Groups from the Family of Civilised Nations to the G20, 1st Edition (New York: Routledge). 